\title{
Does the limpet Patella cochlear fertilize its own algal garden?
}

\author{
Éva E. Plagányi*, George M. Branch \\ Marine Biology Research Institute, Department of Zoology, University of Cape Town, Rondebosch 7701 , \\ South Africa
}

\begin{abstract}
Algal 'gardening' by marine grazers has been described for several species but the possibility that grazers influence their gardens through nutrient enhancement has received less attention. This study examined the hypothesis that nutrient regeneration by the territorial intertidal limpet Patella cochlear enhances the productivity of its algal gardens. Nitrogenous excretions by $P$. cochlear were quantified by (1) measuring urea and ammonium concentrations under limpet shells at low tide; (2) conducting a laboratory experiment to monitor changes in urea, ammonium and nitrate concentrations in the presence of limpets; and (3) using an isotope dilution technique in a field experiment to obtain direct estimates of limpet excretion and algal uptake rates. During low-tide exposure, nitroge-

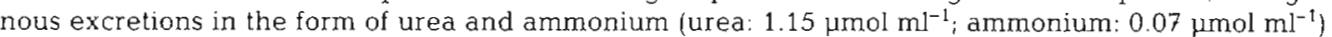
accumulated under $P$. cochlear shells, in close contact with the surrounding algal garden. The average quantity of ammonium excreted by a $30 \mathrm{~mm}$ limpet was estimated as $458.9 \mu \mathrm{g} \mathrm{NH}_{4}-\mathrm{N} \mathrm{d}^{-1}$, which is similar to the estimated nitrogen growth requirements of an algal garden $\left(427.8 \mu \mathrm{g} \mathrm{N}\right.$-growth garden ${ }^{-1}$ $\mathrm{d}^{-1}$ ). Algal uptake rates, estimated in an experimental chamber on the basis of ${ }^{15} \mathrm{~N}$ incorporation by the algae, indicated that ammonium excretions by $P$. cochlear supplied approximately $30 \%$ of the algal garden's daily nitrogen growth requirements. Moreover, the algae demonstrated a potential for 'surge' uptake, an adaptation which would enable them to exploit nitrogenous excretions before these are dissipated by water movement in the field. Our findings show that $P$. cochlear, and potentially other marine gardening species, can enhance the productivity of their algal gardens through the regeneration of limiting nutrients.
\end{abstract}

KEY WORDS: Algal gardening $\cdot$ Marine grazer · Plant-herbivore interaction

\section{INTRODUCTION}

Whereas several studies have examined the question of whether terrestrial plants have co-evolved with their grazers and whether they benefit from being grazed (e.g. McNaughton 1983, Wallace et al. 1985), marine plant-herbivore relationships of this nature have received less attention. However, tight interdependency between grazers and marine plants occurs in 'gardening' interactions in which plant assemblages within a fixed site are modified through the activities of a grazer that selectively enhances the food value of the grazed plants for the grazer (Branch et al. 1992). Marine gardeners include certain nereid polychaetes (Woodin

\footnotetext{
- Present address: Department of Mathematics and Applied Mathematics, University of Cape Town, Rondebosch 7701,

South Africa.E-mail: eva@maths.uct.ac.za
}

1977), tropical reef fish (Sammarco \& Williams 1982, Klumpp \& Polunin 1989) and limpets (Stimson 1973, Branch 1975a, McQuaid \& Froneman 1993).

Algae may be affected in 2 distinct ways by gardening species: through biotic factors such as grazing, and through abiotic factors such as the regeneration of limiting nutrients by the herbivore (Sterner 1986, McCormick \& Stevenson 1991). Grazers can positively affect the supply of nutrients to algal assemblages either by removing overlying cells and facilitating diffusion (McCormick \& Stevenson 1991) or through the excretion of nitrogen (Friedl 1974, Wilkinson \& Sammarco 1983, Grimm 1988, Williams \& Carpenter 1988). Williams \& Carpenter (1988) showed that ammonium excreted by the sea urchin Diadema antillarum may potentially supply up to $19 \%$ of the total nitrogen requirements of the algal turf species grazed by the urchin. McQuaid \& Froneman (1993) compared maxi- 
mum productivity $\left(P_{\max }\right)$ values of grazed and ungrazed Ralfsia verrucosa, which occurs primarily in the gardens of the territorial limpet Patella longicosta, and found that productivity was raised by approximately $30 \%$ in the presence of $P$. longicosta. Although they did not measure nutrient regeneration by the limpet, they attributed the enhanced algal productivity either to this factor or to increased photosynthesis as a direct response to grazing, which increases the number of secondary growth sites (Branch 1975a).

Another South African limpet, Patella cochlear, is also territorial and intimately associated with 'gardens' of specific algae (Branch 1975b). It provides an ideal case to test whether or not nutrient regeneration by a gardening species can boost the production of its gardens. Individual limpets are surrounded by a narrow fringe of fine rhodophyte algae, most frequently Herposiphonia heringii or Gelidium micropterum (Branch 1975a). P. cochlear forms dense populations (up to $1600 \mathrm{~m}^{-2}$ ) low on wave-exposed shores, forming the 'cochlear zone' (Branch 1975a). It powerfully influences community structure, excluding most algae and reducing diversity to sheets of the coralline alga Spongites yendoi and the fringing gardens of red algae. Because of its high density, most juveniles of $P$. cochlear occur on the backs of adults. The adults form scars on the rock which they permanently occupy, feeding by rotating on the scar and grazing their gardens and encrusting corallines in the immediate vicinity.

Patella cochlear is exposed for short periods of the tidal cycle when nitrogenous excretions may build up under the shell and become available for uptake by the associated gardens. Due to the continuous close proximity of the limpet and its algal garden, recycled nutrients in the form of soluble excretions may play an important role in establishing and maintaining algal gardens.

Ammonium is generally considered the most important form of fixed nitrogen supporting the growth of autotrophs and forms the majority of the nitrogen excreted by aquatic heterotrophs (Clarke et al. 1994). Direct field measurements of ammonium regeneration rates by grazers are extremely difficult in coastal regions where physical turbulence is substantial. An alternative is to document the change in ammonium content during incubation under simulated conditions (Billen 1978). Isotope dilution has been used widely, under both natural and simulated conditions, in the empirical determination of ammonium regeneration by natural assemblages of marine organisms (Harrison 1978, Glibert et al. 1982, Probyn 1987).

This study examines the hypothesis that Patella cochlear fertilizes its algal gardens and that the level of fertilization is sufficient to enhance algal productivity.
Specifically, we did the following: (1) determined the nitrogen requirements for algal-garden growth; (2) measured nutrient production by $P$. cochlear during a $26 \mathrm{~h}$ laboratory incubation experiment and obtained direct measurements of nutrient excretion using an isotope dilution method; and (3) related the above rates of nitrogen requirement and production to measurements of uptake rates by algal gardens. Together, our results allow a test of the degree to which nitrogenous excretions of $P$. cochlear may enhance the productivity of its algal gardens.

\section{METHODS}

Experimental site. All field observations, sampling and field experiments were undertaken at Dalebrook $\left(34^{\circ} 6^{\prime} \mathrm{S} 18^{\circ} 28^{\prime} \mathrm{E}\right)$, a marine reserve in False Bay on the east coast of the Cape Peninsula, South Africa.

Algal composition and growth needs. To relate the contribution of a limpet to the potential needs of its algal garden for nitrogen, it was first necessary to determine the chemical composition of the algae comprising the gardens of Patella cochlear. Samples of Herposiphonia heringii and Gelidium micropterum, the dominant algal species, were collected from 20 $P$. cochlear gardens at Dalebrook by gently scraping the algae off the rocks so as to exclude the underlying encrusting coralline species. The fine and intermingled nature of the algae precluded any separation of the 2 species and an estimate of their combined organic composition was considered sufficient for present purposes. The algal samples were dried at $60^{\circ} \mathrm{C}$ for $24 \mathrm{~h}$, ground manually to a homogeneous powder, and dried further at $100^{\circ} \mathrm{C}$. The samples were then analysed for $\mathrm{C}, \mathrm{N}$ and $\mathrm{H}$ content using a Technicon ${ }^{\mathrm{TM}}$ autoanalyser.

The average standing stock of a Patella cochlear garden at Dalebrook is $0.191 \mathrm{~g}$ ash-free dry mass (AFDM) (G.M.B. unpubl. data). Direct field measurements were made of the growth rates of Herposiphonia heringii, the dominant algal species in the gardens. In the absence of grazing, the mean net growth rate for a standard algal garden of this size was estimated to be $0.0124 \mathrm{~g}$ growth garden ${ }^{-1} \mathrm{~d}^{-1}$ (G.M.B. unpubl. data). The results of the HCN analysis were used to convert this growth estimate into an estimate of algal nitrogen requirements for growth. To standardize comparisons of limpet nutrient outputs versus algal garden uptake, we defined a standard limpet-algae garden pair as a limpet of length $30 \mathrm{~mm}$ associated with a $0.191 \mathrm{~g}$ AFDM garden. The wet mass of a $30 \mathrm{~mm}$ limpet was estimated as $0.784 \mathrm{~g}$ using the relationship:

$$
w=1.537 \times 10^{-4} L^{2.5 i}
$$


where $L=$ shell length $(\mathrm{mm})$ and $w=$ wet body mass $(\mathrm{g})$ (Branch 1975a). To standardize $P$. cochlear excretion rates, conversions from wet flesh weight ( $W W$ ) to dry flesh weight $(D W)$ were calculated using the relation: $D W=0.117 \times W W($ Branch \& Newell 1978).

Field measurements of nutrient concentrations under Patella cochlear shells. The in situ accumulation of nutrients by $P$. cochlear was determined directly by extracting and analysing samples of fluid under the shells at low tide. The experiment was conducted in mid-April at Dalebrook. Samples were collected after the limpets had been exposed for approximately $1 \mathrm{~h}$, to allow time for the accumulation of excretory products.

A fine syringe was used to extract a $0.2 \mathrm{ml}$ sample from under the rim of the shells of each of 50 large (>30 mm shell length) Patella cochlear. In each instance, subsamples from 5 individuals were combined to give sufficient material for analysis, and the ten $1 \mathrm{ml}$ resultant samples made up to $5 \mathrm{ml}$ with filtered seawater (Whatman GF/F filter paper was used throughout). Comparable samples of ambient seawater were collected to act as controls. After collection, samples were covered in tinfoil to exclude light and were frozen overnight. Ammonium and urea concentrations were determined in triplicate using the method described by Grasshoff (1976) scaled down for samples of $5 \mathrm{ml}$.

Laboratory determination of Patella cochlear excretion. A 26 h laboratory experiment was conducted to investigate nutrient fluxes in a limpet-algal-garden closed system using $96 \mathrm{P}$. cochlear collected from the low-shore region at Dalebrook. To ensure that limpets were collected without damaging their algal gardens, $P$. cochlear juveniles situated on the shells of larger adults (1 per adult) were used. The flesh of the adult limpets was removed, together with any epifauna and epiflora not associated with the algal gardens, such as encrusting algae growing on the shells.

One litre of filtered seawater was added to each of 9 glass chambers, divided as follows: 4 experimental incubation chambers contained both live juvenile limpets and their associated algal gardens (on adult shells), 4 control chambers contained empty juvenile shells and their algal gardens (on adult shells), and 1 chamber contained filtered seawater only, which acted as a seawater control with respect to ambient nutrient concentrations in seawater (Table 1). The chambers were incubated on a table with flowing seawater in a lighted aquarium. Temperatures were held constant at $17^{\circ} \mathrm{C}$ and airstones were used to aerate each chamber and maintain water circulation. Experiments began following a laboratory acclimation period of $1 \mathrm{~h}$. Three replicate $5 \mathrm{ml}$ samples were withdrawn from each chamber at $2,5,8,11,14,17$ and 26 h after the start of incubation, and were analysed 2 d later for ammonium, urea and nitrate. Prior to analysis, these samples were stored in $16 \times 100 \mathrm{~mm}$ Kimble tubes, sealed with parafilm, and covered with tinfoil to exclude light and frozen.

At the end of the experiment, the limpet bodies were removed from their shells and oven-dried at $60^{\circ} \mathrm{C}$, and a combined measure of dry flesh weight was obtained for each chamber. Limpets in the experiment covered comparable size-class spectra and a linear relationship between limpet mass per chamber and excretion rate was therefore assumed. An estimate of the algal standing stock in each incubation chamber was obtained by scraping the algal gardens off the shells, drying them at $60^{\circ} \mathrm{C}$ and recording the combined dry weight for each chamber. It was virtually impossible to obtain 'pure' algal garden samples due to the difficulty of excluding all of the underlying encrusting coralline algae, but the amounts included were small and it was therefore assumed that the impact of these corallines on the total nutrient pool was negligible.

To test the hypothesis that nitrogenous excretions by Patella cochlear enhance nutrient levels, the limpet and control series were compared by means of a t-test. Ammonium concentrations were corrected for the seawater control levels by subtraction. To obtain an estimate of ammonium excretion independent of other sources of ammonium regeneration, the limpet excretion rate was corrected against the control and the slope of a least-squares regression of ammonium concentration on time was equated with the net excretion rate.

Isotope dilution technique. Direct measurements of nutrient excretion by Patella cochlear and nitrogen

Table 1. Summary of the composition of different treatment types used in the $26 \mathrm{~h}$ laboratory experiment to monitor urea, ammonium and nitrate concentrations

\begin{tabular}{|lcccc|}
\hline Treatment & $\begin{array}{c}\text { No. of } \\
\text { chambers }\end{array}$ & $\begin{array}{c}\text { No. of Patella } \\
\text { cochlear per } \\
\text { incubation chamber }\end{array}$ & $\begin{array}{c}\text { Limpet bodies } \\
\text { removed? }\end{array}$ & $\begin{array}{c}\text { Algal } \\
\text { gardens } \\
\text { present? }\end{array}$ \\
\hline Limpet & 4 & 12 & No & Yes \\
Control & 4 & 12 & Yes & Yes \\
Seawater control & 1 & 0 & - & - \\
\hline
\end{tabular}


uptake by its associated algal gardens were obtained using a ${ }^{15} \mathrm{~N}$ isotope dilution technique.

Field samples of seawater were collected on 13 July 1991 from the intertidal region at Dalebrook, filtered under vacuum (Whatman GF/F-47) and stored overnight in a $16^{\circ} \mathrm{C}$ culture room. Fifty litres of water was measured out into a plastic holding container and spiked with $0.1 \mu \mathrm{mol}{ }^{15} \mathrm{NH}_{4} \mathrm{Cl}(99.7$ atom \%). Water samples $(5 \mathrm{ml})$ for zero-time ammonium determinations were collected in triplicate immediately before and after addition of the ${ }^{15} \mathrm{~N}$ tracer. The samples were stored in the dark over dry ice before analysis. For zero-time isotope ratio determination, $10 \mu \mathrm{mol} \mathrm{NH}_{4} \mathrm{Cl}$ was added to exactly $900 \mathrm{ml}$ of the filtrate (to satisfy the mass requirements for atomic spectrometry), and the mixture was stored frozen.

To simulate most closely the in situ conditions of Patella cochlear, 6 clear incubation chambers were floated in the Dalebrook tidal swimming pool by strapping them in a random order to an anchored floating beam. One-third to one-half of each bucket was immersed in the water, ensuring a uniformity of ambient and experimental water temperature $\left(14\right.$ to $\left.16^{\circ} \mathrm{C}\right)$. A 61 subsample of the spiked filtrate was added to each of these incubation chambers. Limpets (12 per container) plus their associated algal gardens (again on the backs of adult host shells from which the limpet body had been removed) were added to each of 3 experimental chambers. The 3 control chambers contained juvenile limpet shells with their associated algal gardens (on adult shells), but no living limpets. After 1 , 2,5 and $7 \mathrm{~h}$ of incubation, a $5 \mathrm{ml}$ sample (for ammonium analysis) and a $900 \mathrm{ml}$ sample (for determination of the aqueous ammonium enrichment) were extracted.

Algal garden samples collected at the end of the experiment were frozen overnight and then concentrated on glass fibre filter paper by rinsing with filtered seawater. Samples were oven-dried $\left(80^{\circ} \mathrm{C}\right)$ and finely ground before being weighed (to estimate total nitrogen), and five $2 \mathrm{mg}$ subsamples of each were sealed into $5 \times 8 \mathrm{~mm}$ tin capsules for determination of ${ }^{15} \mathrm{~N}$ incorporation by the particulate fraction. To standardize ammonium ion excretion rates, the combined ashfree dry body mass of each set of limpets was used as a measure of the limpet standing stock active in the excretion process

Aqueous ammonium was recovered from the $900 \mathrm{ml}$ samples by diffusion. Sufficient $\mathrm{MgO}$ was added to each sample to raise the $\mathrm{pH}$ above 9 . A $25 \mathrm{~mm}$ glassfibre filter wetted with $0.05 \mathrm{ml} 12 \mathrm{~N} \mathrm{H}_{2} \mathrm{SO}_{4}$ was then suspended above the sample and the bottle capped tightly. The bottles were left at room temperature for about 3 wk, during which time the aqueous ammonium was recovered on the filter as $\left(\mathrm{NH}_{4}\right)_{2} \mathrm{SO}_{4}$. The fil- ters were oven-dried $\left(50^{\circ} \mathrm{C}\right)$ overnight and 10 circular discs punched from each and sealed in tin capsules. Enrichment with ${ }^{15} \mathrm{~N}$ was determined for both the aqueous and the particulate fraction with the use of ANCA-MS (Automated N/C Analyser-Mass Spectrometer) located at the Plymouth Marine Laboratory (United Kingdom).

Ammonium uptake rates by the algal gardens $(u)$ were calculated using the formulation given by Glibert et al. (1982) in which correction is made for isotopic dilution:

$$
u=\frac{P E \times P N}{R \times t}
$$

where $P E=$ percent ${ }^{15} \mathrm{~N}$ enrichment of the particulate fraction in excess of the natural abundance; $P N=$ particulate nitrogen concentration $\left(\mu \mathrm{mol} \mathrm{l}{ }^{-1}\right) ; t=$ duration of incubation (h); and $R=$ exponential average aqueous ${ }^{15} \mathrm{~N}$ enrichment:

where

$$
R=\frac{R_{0}}{k t\left(1-\mathrm{e}^{-k t}\right)}
$$

$$
k=\frac{-\ln \left(R_{l} / R_{0}\right)}{t}
$$

and $R_{0}$ and $R_{t}$ are the measured aqueous ${ }^{15} \mathrm{~N}$ enrichments at the beginning and end of an incubation respectively.

Ammonium regeneration rates $(r)$ were calculated from a modified form of the Blackburn (1979) and Caperon et al. (1979) model:

$$
r=\frac{\ln \left(R_{t} / R_{0}\right)}{\ln \left(S_{t} / S_{0}\right)} \frac{\left(S_{0}-S_{t}\right)}{t}
$$

where $S_{0}$ and $S_{t}=$ aqueous ammonium concentrations at the start and finish of an experiment. Values were corrected for the decreasing volume in the chambers over time.

\section{RESULTS}

\section{Algal composition and growth needs}

The percentages of dry algal garden matter contributed by carbon, nitrogen and hydrogen were 36.1 , 4.2 and 3.4 respectively. The average $\mathrm{C}: \mathrm{N}$ ratio for the algal gardens was 10.5. The measured nitrogen content $(3.5 \%)$ of Patella cochlear gardens was used in conjunction with the previously determined growth rate of $0.0124 \mathrm{~g} \mathrm{garden}^{-1} \mathrm{~d}^{-1}$ (see 'Methods') to estimate that the algal requirements of nitrogen for growth of a 'standard' garden of $0.191 \mathrm{~g}$ AFDM is $427.8 \mu \mathrm{g} \mathrm{N}$ garden ${ }^{-1} \mathrm{~d}^{-1}$. 
Table 2. Mean nutrient concentrations ( $\mu \mathrm{mol} \mathrm{ml^{-1 } )}( \pm \mathrm{SE})$ determined as the mean of ten $1 \mathrm{ml}$ samples (each composed of five $0.2 \mathrm{ml}$ subsamples) of fluid extracted from under Patella cochlear shells at low tide

\begin{tabular}{|lcc|}
\hline & $\begin{array}{c}\text { Ammonium }\left(\mu \mathrm{mol} \mathrm{m} l^{-1}\right) \\
\mathrm{NH}_{4}\end{array}$ & $\begin{array}{c}\text { Urea }\left(\mu \mathrm{mol} \mathrm{ml} l^{-1}\right) \\
\mathrm{CO}\left(\mathrm{NH}_{2}\right)_{2}\end{array}$ \\
\hline $\mathrm{n}$ & 10 & 10 \\
$\begin{array}{l}\text { P. cochlear } \\
\text { Seawater control } \\
\text { aelow the lower limit of detection }\end{array}$ & $\begin{array}{c}0.071(0.015) \\
0^{\mathrm{a}}\end{array}$ \\
\hline
\end{tabular}

\section{Production of nutrients by Patella cochlear}

\section{Nutrient concentrations during low tide exposure}

High concentrations of ammonium and urea were recorded under Patella cochlear shells at low tide (Table 2), suggesting that nitrogenous excretions are likely to be available for algal uptake since dissipation of $P$. cochlear excretions was neither immediate nor complete. Ammonium and urea concentrations were below the lower limits of detection in adjacent ambient seawater. Mean urea concentrations were significantly higher than mean ammonium concentrations (MannWhitney test, $p<0.05$ ), indicating that urea is the primary excretory product accumulating at low tide. Simple diffusion of the fluid from the rim of the shell to adjoining algae will ensure that the algae are exposed to these concentrations of nutrients

\section{Experimental determination of excretion rates}

Ammonium concentrations were significantly greater in the incubation chambers containing limpets than in the control chambers containing limpet shells from which the flesh was removed $\left(t_{0.05(2) .54}=2.38\right.$, $p<0.05$ ). Ammonium concentrations in pure seawater $\left(0.011 \mu \mathrm{mol} l^{-1}, \mathrm{SE} \pm 0.001\right)$ remained approximately constant over the $26 \mathrm{~h}$ sampling period. The limpet excretion rate per sampling period was estimated as the rate of regeneration of ammonium in chambers containing live limpets minus the mean levels in the control chambers with empty limpet shells. Ammonium excretion rates were approximately constant throughout the experimental period (Fig. 1) at $1.085 \mu \mathrm{mol} \mathrm{l^{-1 }} \mathrm{h}^{-1}$ $(\mathrm{r}=0.975 ; \mathrm{n}=31 ; \mathrm{p}<0.001)$. Expressing this in terms of the amount of $\mathrm{NH}_{4}-\mathrm{N}$ excreted yields $15.19 \mu \mathrm{g}$ $\mathrm{NH}_{4}-\mathrm{N} \mathrm{h}^{-1} \mathrm{~g}^{-1}$ of limpet or $285.815 \mu \mathrm{g} \mathrm{NH}_{4}-\mathrm{N} \mathrm{d}^{-1}$ per standard $30 \mathrm{~mm}$ limpet.

The release of urea by Patella cochlear (corrected as before for the control) occurred as a single event imme-

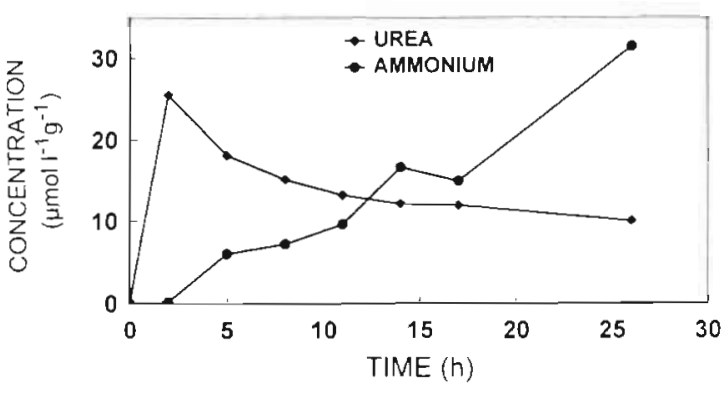

Fig. 1. Concentrations of ammonium and urea, corrected for control levels, and expressed per gram dry weight of limpet tissue, during the $26 \mathrm{~h}$ laboratory experiment using incubation chambers containing Patella cochiear individuals and their associated algal gardens

diately after the limpets were submerged (Fig. 1), with urea levels decreasing soon afterwards to a lower and almost constant level. Assuming that the initial peak in urea concentration represented the total amount of urea accumulated during the $2 \mathrm{~h}$ period of low-tide exposure prior to collection plus the $2 \mathrm{~h}$ incubation time, i.e. over a $4 \mathrm{~h}$ period, this yields a peak urea excretion rate of $18.414 \mu \mathrm{g} \mathrm{CO}\left(\mathrm{NH}_{2}\right)_{2}-\mathrm{N} \mathrm{h}^{-1}$ per standard limpet.

There were no significant differences between nitrate concentrations measured in the experiment and control chambers ( $\left.t_{0.05(2), 54}=-1.26, p=0.21\right)$, indicating that nitrate was not excreted by Patella cochlear. Nitrate concentrations decreased with time in both the experimental and control chambers (Fig. 2), probably due to uptake by the algal gardens.

\section{Direct measurements of ammonium regeneration}

Enhancement of ambient $\mathrm{NH}_{4}-\mathrm{N}$ levels due to the addition of ${ }^{15} \mathrm{~N}$ was calculated as approximately $6.3 \%$, indicating a low ratio of ${ }^{15} \mathrm{~N}$ to the total nitrogen pool. The approximately exponential decrease in ${ }^{15} \mathrm{~N}$ atom $\%$ enrichment $(R)$ with time (Fig. 3a) indicates that regeneration of ${ }^{14} \mathrm{NH}_{4}{ }^{+}$occurred in both the experimental and the control incubation chambers. The level of enrichment $(R)$ was nonetheless significantly greater in the experiment than in the control (Mann-Whitney test; $\left.U_{0.05(2), 15,15}=64, \mathrm{p}<0.05\right)$.

The rate of ammonium regeneration was consistently higher in the limpet than in the control incubation chambers (Fig. 3b). Ammonium concentrations peaked within $1 \mathrm{~h}$ of submersion of the limpets, whereas the regeneration rate in the control chambers without limpet bodies remained consistently low. Subtraction of the control regeneration rate from the experimental rate yields a net ammonium regeneration rate that is a function of limpet excretion alone. 


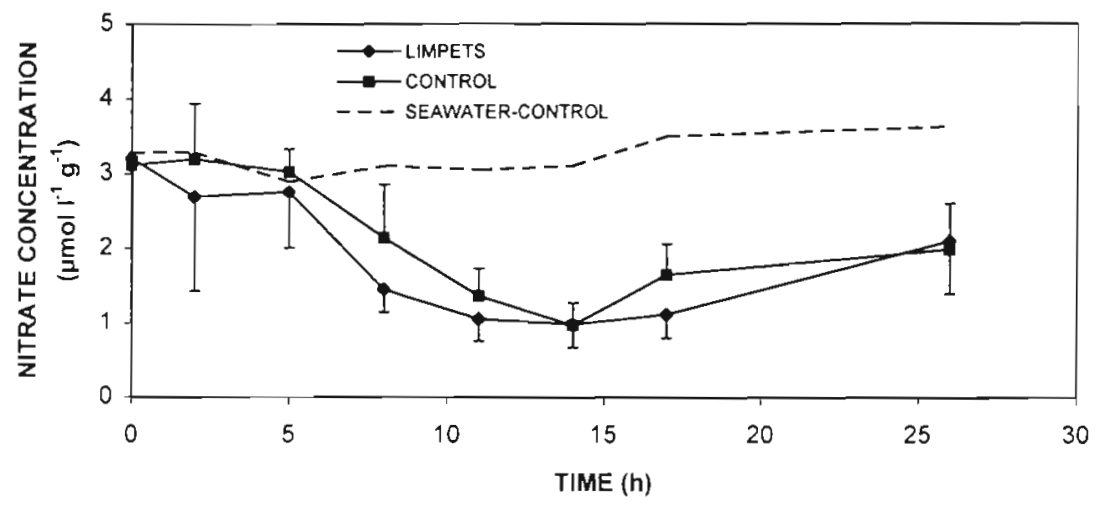

Fig. 2. Temporal changes in nitrate concentrations (mean $\pm \mathrm{SD}$ ) during the $26 \mathrm{~h}$ laboratory experiment. Changes in incubation chambers containing Patella cochlear individuals and their associated algal gardens and in control chambers without live limpets are shown relative to a seawater control
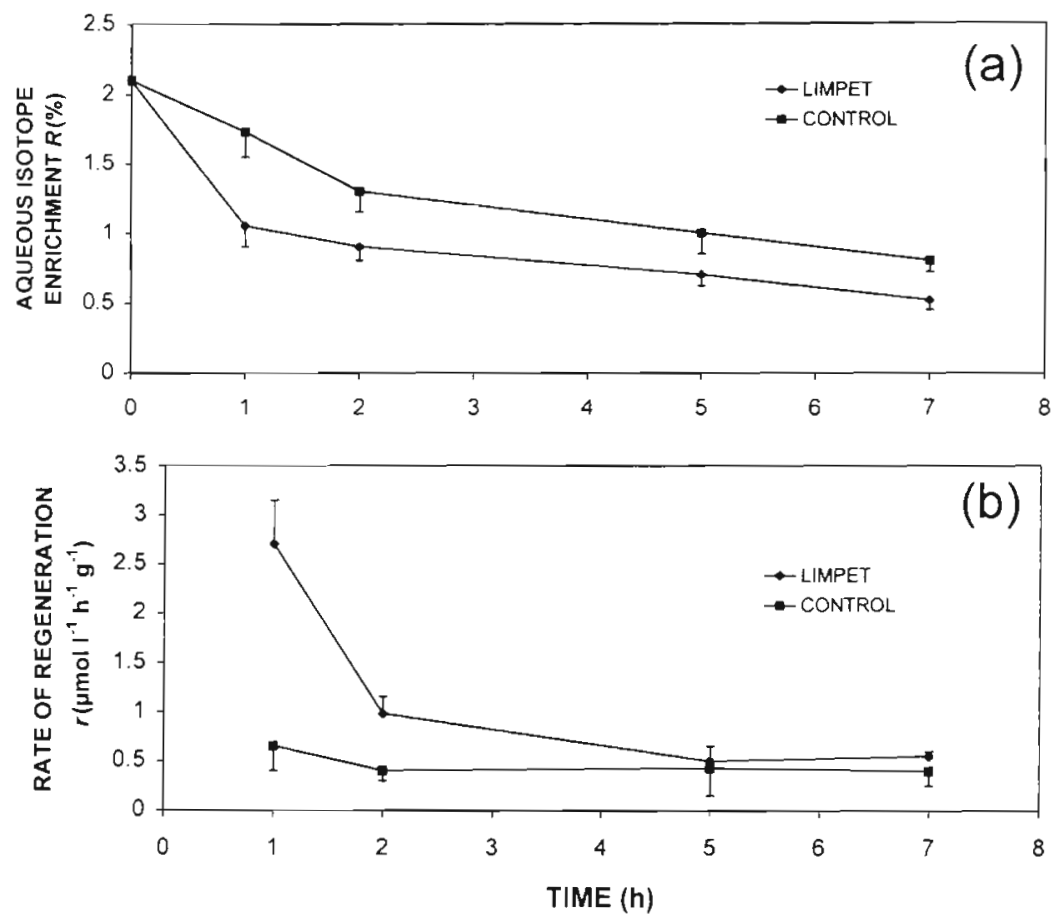

Fig. 3. (a) The aqueous isotope enrichment (mean \pm SD) and (b) rate of ammonium regeneration (mean $\pm \mathrm{SD}$ ) measured using a

${ }^{15} \mathrm{~N}$ isotope dilution technique

The average excretion rate measured was $24.4 \mu \mathrm{g}$ $\mathrm{NH}_{4}-\mathrm{N} \mathrm{h}^{-1} \mathrm{~g}^{-1}$ of limpet or $458.9 \mu \mathrm{gH}_{4}-\mathrm{N} \mathrm{d}^{-1}$ for a standard $30 \mathrm{~mm}$ limpet.

\section{Uptake by the algal gardens}

\section{Urea uptake rates}

The peak urea excretion rate, measured in the laboratory experiment and corrected for the control, was 18.414 $\mathrm{\mu g} \mathrm{CO}\left(\mathrm{NH}_{2}\right)_{2}-\mathrm{N} \mathrm{h}^{-1}$ per standard limpet. Given the rate at which urea concentrations decreased in chambers containing live limpets (Fig. 1), a 'standard' algal garden associated with the limpets absorbed a maximum of $7.8 \mu \mathrm{g} \mathrm{CO}\left(\mathrm{NH}_{2}\right)_{2}-\mathrm{N} \mathrm{h}^{-1}$.

\section{Ammonium uptake rates}

Estimates of uptake rates were based on the amount of ${ }^{15} \mathrm{~N}$ which appeared in the algae, as measured in the particulate fraction. It was assumed that uptake was directly proportional to algal standing stock and hence algal standing stock measurements obtained from each incubation chamber were used to convert uptake rates to uptake per average $0.191 \mathrm{~g}$ AFDM algal garden. Daily uptake rates calculated on the basis of $\%{ }^{15} \mathrm{~N}$ incorporation by the algal gardens showed that uptake rates in the experimental chambers containing live limpets (126.1 $\mu \mathrm{g} \mathrm{NH}_{4}-\mathrm{N}$ garden ${ }^{-1} \mathrm{~d}^{-1}$ ) were approximately twice those estimated for the control chambers $\left(62.8 \mu \mathrm{g} \mathrm{NH} \mathrm{NH}_{4}-\mathrm{N}\right.$ garden ${ }^{-1} \mathrm{~d}^{-1}$ ). The direct measurements of ammonium uptake in the experimen- 
tal and control chambers corresponded respectively to 29.5 and $14.7 \%$ of a standard algal garden's nitrogen requirements for growth.

\section{DISCUSSION}

\section{Algal composition and growth needs}

The algae comprising Patella cochlear gardens, as with those in the gardens of fish (Montgomery 1980, Klumpp et al. 1987, Russ 1987), have a high organic content and low $\mathrm{C}: \mathrm{N}$ ratio-factors which are thought to increase the food value of algae in gardens (Branch et al. 1992). The C: $N$ ratio of 10.46 is below the median value calculated for algae inside territories of the tropical damselfish (Russ 1987), but corresponds well with values obtained for 11 species of 'dietary' rhodophytes from a rocky shore in California (Neighbors \& Horn 1991). Low C:N ratios are characteristic of high productivity (Niell 1976).

The nitrogen growth requirements of Herposiphonia heringii, one of the dominant algal species in Patella cochlear algal gardens, was estimated as $427.8 \mu \mathrm{g} \mathrm{N}$ growth garden ${ }^{-1} \mathrm{~d}^{-1}$, which can be compared with the amount of nitrogen excreted per limpet as follows below.

\section{Nitrogenous excretion by Patella cochlear}

Measurements of ammonium and urea concentrations under the rim of Patella cochlear shells at low tide (Table 2) indicated that nitrogenous excretions accumulate under the shell and, thus, may diffuse out and become available for uptake by the surrounding algal garden. Direct measurements (using an isotope dilution method) of ammonium excretion rates by submerged limpets suggested that an average $30 \mathrm{~mm}$ limpet produces $458.9 \mu \mathrm{g} \mathrm{NH}_{4}-\mathrm{N} \mathrm{d}^{-1}$, which is on approximately the same scale as the estimated field growth requirements of an average algal garden.

The rates of ammonium excretion measured in the present study $\left(15.2 \mu \mathrm{g} \mathrm{NH}-\mathrm{N} \mathrm{h}^{-1} \mathrm{~g}^{-1}\right.$ in the laboratory experiment; $24.4 \mathrm{\mu g} \mathrm{NH}_{4}-\mathrm{N} \mathrm{h}^{-1} \mathrm{~g}^{-1}$ in the isotope dilution experiment) were comparable with those reported for other marine gastropods (Crisp et al. 1981, Macé \& Ansell 1982). The refined estimates of ammonium excretion obtained using the ${ }^{15} \mathrm{~N}$ isotope dilution technique provided a direct measurement of the average rate of ammonium excretion which was $60 \%$ more than that obtained from the indirect measurement in the laboratory, presumably because the laboratory results were confounded by the same technical difficulties reported elsewhere: unassimilated nitrogen may be voided with the fæces, bacterial action may alter nitrogen concentrations over long incubation times, and disturbances affecting physiological condition may induce changes in excretion rates (Bayne \& Scullard 1977, Crisp et al. 1981, Hughes 1986).

The peak in aqueous urea concentration recorded shortly after limpets were submerged in experimental chambers is explained by the elevated urea concentrations measured under Patella cochlear shells when they were exposed to the air at low tide. As with most other marine invertebrates, $P$, cochlear excreted predominantly ammonia, except during periods (such as low tide) when water supply was critical and nitrogen was extracted in the more concentrated but less toxic form of urea (Clarke et al. 1994). Urea was apparently not excreted following immersion of the limpets, because the rate of decline of urea in treatments containing limpets was identical to that in shell controls. Thus, urea will not continually be available for uptake by algae, and urea excretions may at best serve to boost the supply of nitrogen available to the algal gardens during exposure at low tide.

Algae may also supplement their nitrogen requirements by utilizing nitrate, and the decline of nitrate in the chambers containing both limpets and shells alone was probably due to uptake by the algal gardens. However, we found no evidence that Patella cochlear excretes nitrogen in the form of nitrates (Fig. 2).

\section{Nutrient uptake by algal gardens}

Although the nitrogen growth requirements of a 'standard' garden were estimated to be $427.8 \mu \mathrm{g} \mathrm{N}$ garden ${ }^{-1} \mathrm{~d}^{-1}$ and a $30 \mathrm{~mm}$ limpet associated with such a garden can supply $458.9 \mu \mathrm{g} \mathrm{NH}_{4}-\mathrm{N} \mathrm{d}^{-1}$, not all of this output will be taken up by the algal garden. A better estimate of actual uptake was obtained through the experiments yielding direct measurements of uptake rates. Results obtained from both the $26 \mathrm{~h}$ laboratory study and the $7 \mathrm{~h}$ field study indicated that algae in the gardens of Patella cochlear are capable of utilizing urea, ammonium and nitrate as nitrogen sources. It is energetically advantageous for a plant to utilize ammonium rather than nitrate (Turpin 1991), but maximum rates of nitrate and ammonium uptake may nonetheless be maintained simultaneously if nitrogen is limiting (Thomas \& Harrison 1987). Antia et al. (1977) found that of 26 marine microplanktonic algae examined $88 \%$ grew well when urea was the sole nitrogen source, often better than on ammonium. We monitored urea concentrations during the $26 \mathrm{~h}$ laboratory study and found that aqueous urea concentrations were highest soon after limpets were submerged in 
experimental chambers, but decreased rapidly thereafter (Fig. 1), suggesting that the algae comprising the limpets' gardens were capable of absorbing urea when it is available, although we cannot be certain that the decline was not caused by bacterial conversion. Ignoring possible bacterial conversion, our results indicated that an average algal garden may absorb as much as $7.8 \mu \mathrm{g} \mathrm{CO}\left(\mathrm{NH}_{2}\right)_{2}-\mathrm{N} \mathrm{h}^{-1}$ and therefore potentially exploit at least a third of the urea supply accumulated under $P$. cochlear shells during periodic periods of exposure. Unlike the case for ammonium, for which we measured direct uptake by the algae, we cannot be certain that they do take up urea.

The capacity for 'surge' uptake, whereby nitrogen, and particularly ammonium, are taken up at elevated rates compared with plant growth rate (Goldman \& Glibert 1982, Lapointe 1985), is a necessary prerequisite if algae are to exploit the nitrogenous excretions of Patella cochlear before these are dissipated by water movement. The high capacity of red algae to respond to changing pulses of $\mathrm{NH}_{4}{ }^{+}$and to take up large amounts has been demonstrated experimentally for Gracilariopsis lemaneiformis (Vergara et al. 1995). Close coupling between intermittent $\mathrm{NH}_{4}{ }^{+}$pulses and algal uptake allows algae to maintain balanced growth in a patchy environment (Collos 1986). Direct measurements of ammonium uptake rates in a closed system containing live limpets (126.1 $\mu \mathrm{g} \mathrm{NH}_{4}-\mathrm{N}$ gar$\operatorname{den}^{-1} \mathrm{~d}^{-1}$ ) indicated elevated ammonium uptake in response to locally enhanced levels when compared with rate of uptake in closed systems with empty shells only (62.8 $\mu \mathrm{g} \mathrm{NH}_{4}-\mathrm{N}_{\text {garden }}{ }^{-1} \mathrm{~d}^{-1}$ )

The ammonium uptake rates calculated on the basis of ${ }^{15} \mathrm{~N}$ incorporation by the particulate (algal) fraction suggested that, in terms of ammonium alone, the soluble excretions of Patella cochlear may supply almost one-third of the nitrogen required for growth of its algal garden. This result is likely to be conservative because it will be downwardly biased if losses of ${ }^{15} \mathrm{~N}$ occurred during our experiment as a result of, for example, nitrification, adsorption of $\mathrm{NH}_{4}^{+}$to the container walls or suspended particles, and release of ${ }^{15} \mathrm{~N}$ as dissolved organic nitrogen (Laws 1984). The experimental results also ignore the fact that algal productivity is enhanced by grazing (Branch 1981), which will increase the nitrogen uptake required by the plant, whereas our estimate of the nitrogen requirements is based on experimental conditions that did not include the effect of grazing. It should also be noted that under field conditions limpets obtain food not only from the algal gardens but also from encrusting corallines and microalgae (Branch 1971, 1980). This explains why the iimpets are able to produce quantities of nitrogen in their excreta which are on the same scale as the requirements of the algal garden.

\section{Potential contribution of Patella cochlear excretions}

Based on our observations that in the field individuals of Patella cochlear represent microenvironments of elevated nitrogen concentrations and the fact that the limpets excrete in close proximity to their algal gardens, the present study is the first to explore more fully the possibility that nutrient inputs from a territorial limpet species are sufficient to boost the production of its gardens. At low tide, water exchange with the surroundings is reduced or absent, and we found that soluble urea and ammonium excreted by $P$. cochlear accumulate to levels at which they could potentially contribute significantly to the nitrogen requirements of the algae in the gardens. This is because, although nitrogen regeneration by any limpet would presumably enhance nutrient availability to macroalgae, in this case, the algae are regularly exposed to regenerated nitrogen by virtue of the intimate limpet-algae garden association.

The general body of evidence presented in this study indicates excretion rates were substantially in excess of uptake rates. Were it not for losses due to water movement, ammonium recycling alone could contribute substantially to maintaining algal garden stocks and productivity rates. The exact daily contribution of recycled nutrients in the form of soluble excretions to algal gardens is difficult to quantify in situ, but the magnitude of Patella cochlear nutrient regeneration coupled with the ability of these algae to respond rapidly to changes in nutrient levels supports our hypothesis that these nitrogen supplements do influence algal productivity. This, in turn, increases the primary production available for ingestion by the limpet. As with the non-obligate mutualism defined between the territorial limpet $P$. longicosta and the alga Ralfsia verrucosa (McQuaid \& Froneman 1993), both $P$. cochlear and its algal garden may therefore benefit from their association. This case is thus another example in which the interaction between a grazer and its food plant contains a positive feedback enhancing the growth of the plant. Most herbivoreplant interactions are viewed purely from the negative impact that grazers have on their food plant. Our study adds to the emphasis of a small group of papers (e.g. McNaughton 1984, Carpenter 1986, Branch et al. 1992) showing grazers can have positive effects on their food plants.

Acknowledgements. A number of people assisted us in the field $d_{i}$ their help is gratefully acknowledged. Thanks to $T$. Probyn, M. Lucas, D. Gianakouros, G. Burbridge and S. Mostert for their help in analysing the field and laboratory samples. We thank the staff of the Plymouth Marine Laboratory for analysing our ${ }^{15} \mathrm{~N}$ samples. Thanks to 4 anonymous referees for useful suggestions and revisions. 'The first author 
was the recipient of a bursary from the Foundation for Research Development (FRD) and this body and the South African Network for Coastal and Oceanographic Research (SANCOR) provided funding for the research.

\section{LITERATURE CITED}

Antia NJ, Berland BJ, Bonin DJ, Maestrini SJ (1977) Effects of urea concentration in supporting growth of certain microplanktonic algae. Phycologia 16:105-111

Bayne BL, Scullard C (1977) Rates of nitrogen excretion by species of Mytilus (Bivalvia: Mollusca) J Mar Biol Assoc UK 57:355-369

Billen GA (1978) A budget of nitrogen cycling in North Sea sediments off the Belgian coast. Estuar Coast Mar Sci 7 : $127-146$

Blackburn TH (1979) Method for measuring rates of $\mathrm{NH}_{4}$ turnover in anoxic marine sediment, using a ${ }^{15} \mathrm{~N}-\mathrm{NH}_{4}$ dilution technique. Appl Environ Microbiol 37:760-765

Branch GM (1971) The ecology of Patella Linnaeus from the Cape Peninsula, South Africa. I. Zonation, movements and feeding. Zool Afr 6(1):1-38

Branch GM (1975a) Mechanisms reducing intraspecific competition in Patella spp.. migration, differentiation and territorial behaviour. J Anim Ecol 44:575-600

Branch GM (1975b) Intraspecific competition in Patella cochlear Born. J Anim Ecol 44:263-282

Branch GM (1980) Territoriality in Iimpets: manipulative experiments and energy budgets. J Malacol Soc Aust 4: $245-246$

Branch GM (1981) The biology of limpets: physical factors, energy flow, and ecological interactions. Oceanogr Mar Biol Annu Rev 19:235-380

Branch GM, Newell RC (1978) A comparative study of metabolic energy expenditure in the limpets Patella cochlear $P$. oculus and P. granularis. Mar Biol 49:351-361

Branch GM, Harris JM, Parkins C, Bustamante RH, Eekhout S (1992) Algal 'gardening' by grazers: a comparison of the ecological effects of territorial fish and limpets. In: John DM. Hawkins SJ, Price JH (eds) Plant-animal interactions in the marine benthos. Systematics Association Special Volume, Clarendon Press, Oxford, no. 46, p 405-423

Caperon J, Schell D, Hirota J, Laws E (1979) Ammonium excretion rates in Kaneohe Bay, Hawaii, measured by an ${ }^{15} \mathrm{~N}$ isotope dilution technique. Mar Biol 54:33-40

Carpenter RC (1986) Partitioning herbivory and its effects on coral reef algal communities. Ecol Monogr 56(4):345-363

Clarke A, Prothero-Thomas E, Whitehouse MJ (1994) Nitrogen excretion in the antarctic limpet Nacella concinna (Strebel 1908). J Moll Stud 60:141-147

Collos Y (1986) Time-lag algal growth dynamics: biological constraints on primary production in aquatic environments. Mar Ecol Prog Ser 33:193-206

Crisp M. Gill CW, Thompson MC (1981) Ammonia excretion by Nassarius reticulatus and Buccinum undatum (Gastropoda: Prosobranchia) during starvation and after feeding. J Mar Biol Assoc UK 61:381-390

Friedl FE (1974) Nitrogen excretion by the freshwater snail Lymnaea stagnalis jugularis Say. Comp Biochem Physiol $49: 617-622$

Glibert PM, Lipschultz F, McCarthy JJ, Altabet MA (1982) Isotope dilution models of uptake and remineralization of ammonium by marine plankton. Limnol Oceanogr 27:639-650

Goldman JC, Glibert PM (1982) Comparative rapid ammonium uptake by four species of marine phytoplankton. Limnol Oceanogr 27:814-827
Grasshoff K (1976) Methods of seawater analysis. Verlag Chemie, Weinheim

Grimm NB (1988) Role of macroinvertebrates in nitrogen dynamics of a desert stream. Ecology 69:1884-1893

Harrison WG (1978) Experimental measurements of nitrogen remineralization in coastal waters. Limnol Oceanogr 23: $684-694$

Hughes RN (1986) A functional biology of marine gastropods. Croom Helm, London

Klumpp DW, Polunin NVC (1989) Partitioning among grazers of food resources within damselfish territories on a coral reef. J Exp Mar Biol Ecol 125:145-169

Klumpp DW, McKinnon D, Daniel P (1987) Damselfish territories: zones of high productivity on coral reefs. Mar Ecol Prog Ser 40:41-51

Lapointe BE (1985) Strategies for pulsed nitrogen supply to Gracilaria cultures in the Florida Keys: interactions between concentration and frequency of nutrient pulses. J Exp Mar Biol Ecol 93:211-222

Laws E (1984) Isotope dilution models and the mystery of the vanishing ${ }^{15} \mathrm{~N}$. Limnol Oceanogr 29:379-386

Mace A. Ansell A.D (1982) Respiration and nitrogen excretion of Polinices alderi (Forbes) and Polynices catena (Da Costa) (Gastropoda: Naticidae). J Exp Mar Biol Ecol 60: 275-295

McCormick PV, Stevenson RJ (1991) Grazer control of nutrient availability in the periphyton. Oecologia 86:287-291

McNaughton SJ (1983) Compensatory plant growth as a response to herbivory. Oikos 40:329-336

McNaughton SJ (1984) Grazing lawns: animals in herds, plant form, and coevolution. Am Nat 124:863-886

McQuaid CD, Froneman PW (1993) Mutualism between the territorial intertidal limpet Patella longicosta and the crustose alga Ralfsia verrucosa. Oecologia 96:128-133

Montgomery WL (1980) The impact of non-selective grazing by the giant blue damselfish, Microspathodon dorsalis, on algal communities in the Gulf of California, Mexico. Bull Mar Sci 30:290-303

Neighbors MA, Horn MH (1991) Nutritional quality of macrophytes eaten and not eaten by two temperate-zone herbivorous fishes: a multivariate comparison. Mar Biol 108: $471-476$

Niell FX (1976) C:N ratio in some marine macrophytes and its possible ecological significance. Bot Mar 19:347-350

Probyn TA (1987) Ammonium regeneration by microplankton in an upwelling environment. Mar Ecol 37:53-64

Russ GR (1987) Is the rate of removal of algae by grazers reduced inside territories of the tropical damselfish? J Exp Mar Biol Ecol 110:1-17

Sammarco PW, Williams AH (1982) Damselfish territoriality: influence on Diadema distribution and implications for coral community structure. Mar Ecol Prog Ser 8:53-59

Sterner RW (1986) Herbivores' direct and indirect effects on algal populations. Science 231:605-606

Stimson J (1973) The role of the territory in the ecology of the intertidal limpet, Lottia gigantea (Gray). Ecology 54: $1020-1030$

Thomas TE, Harrison PJ (1987) Rapid ammonium uptake and nitrogen interactions in five intertidal seaweeds grown under field conditions. J Exp Mar Biol Ecol 107:1-8

Turpin DH (1991) Effects of inorganic nitrogen availability on algal photosynthesis and carbon metabolism. J Phycol 27: $14-20$

Vergara JJ, Bird KT, Niell FX (1995) Nitrogen assimilation following $\mathrm{NH}_{4}{ }^{+}$pulses in the red alga Gracilariopsis lemaneitormis: effect on C metabolism. Mar Ecol Prog Ser $122: 253-263$ 
Wallace LL, MacNaughton SJ, Coughenour MB (1985) Effects of clipping and four levels of nitrogen on the gas exchange, growth and production of two East African graminoids. Am J Bot 72:222-230

Wilkinson CR, Sammarco PW (1983) Effects of fish grazing and damselfish territoriality on coral reef algae. II. Nitrogen fixation. Mar Ecol Prog Ser 13:15-19

Editorial responsibility: Otto Kinne (Editor), Oldendorf/Luhe, Germany
Williams SL, Carpenter RC (1988) Nitrogen-limited primary productivity of coral reef algal turfs: potential contribution of ammonium excreted by Diadema antillarum. Mar Ecol Prog Ser 47:145-152

Woodin SA (1977) Algal 'gardening' behaviour by nereid polychaetes: effects on soft-bottom community structure. Mar Biol 44:39-42

Submitted: May 3, 1999; Accepted: September 14, 1999 Proofs received from author(s): February 22, 2000 